\title{
Genomic imprinting: a possible mechanism for the parental origin effect in Huntington's chorea
}

\author{
WOLF REIK \\ From the Department of Molecular Embryology, Institute of Animal Physiology and Genetics Research, \\ Cambridge CB2 4AT.
}

SUMMARY Huntington's disease (HD) is an autosomal dominant condition with almost complete penetrance. The age of onset of the symptoms, however, is variable and depends on the parental origin of the gene. A high proportion of early onset cases inherit the HD gene from their father, whereas a considerable proportion of late onset cases inherit the gene from their mother. Modification of the HD gene by maternally inherited extrachromosomal factors has been invoked to account for the parental origin effect. Recent experimental evidence suggests genomic imprinting as an alternative mechanism, by which the gene itself becomes modified in a different way depending on whether it is passed through the maternal or the paternal germline. This modification may involve methylation of DNA and could result in earlier or higher level expression of the gene when it is transmitted by the father.

\section{Parental origin effect in Huntington's disease}

The sex of the affected parent has a profound effect on the age of onset in HD. Paternal transmission of the gene will, on average, lead to an earlier onset of symptoms than will maternal transmission. ${ }^{1-9}$ Most importantly, this parental origin effect seems to operate at all ages of onset in HD. ${ }^{8}$ Among the many hypotheses to explain this observation, maternal transmission of cytoplasmic factors, such as mitochondria, that would modify onset of HD has been advocated strongly. ${ }^{369}$ In this model, exclusive maternal transmission of protective factors to the cytoplasm of the oocyte delays the expression of the HD gene in the resulting offspring. Paternal transmission, on the other hand, produces a zygote that carries the mutant gene but has a wild type cytoplasm since it derives from an unaffected female. No protection against the HD gene is conferred by normal cytoplasm and hence earlier onset of symptoms ensues.

A number of observations are difficult to reconcile with this model. First, mother-offspring correlation of age at onset should be significantly higher than father-offspring correlation of age at onset, since the mother should carry the same protection agents in her cytoplasm as the offspring, whereas cytoplasmic components should change following paternal trans- mission. There is conflicting evidence on this point, however; for example, Myers et al $^{4} 68$ and Brackenridge $^{10}$ found no significant difference between the two correlations, whereas Boehnke et $\mathrm{al}^{3}$ and Farrer and Conneally ${ }^{9}$ reported an increase in the motheroffspring correlation over the father-offspring correlation. Second, cytoplasmic factors would be expected to be passed on through multiple generations of affected female ancestors. These multigenerational influences would manifest themselves as reproductive advantage or as an effect of the sex of the affected grandparent. Extensive studied, of HD families show that there is neither a reproductive advantage for late onset women, ${ }^{811}$ nor does the sex of the affected grandparent influence age at onset in offspring that receive the gene from their mother. ${ }^{8}$ Indeed, it appears that the effect of the sex of the afflicted parent is reversible within a single generation. ${ }^{8}$ Thus, any putative protective agent in the cytoplasm of the oocyte has to be selected for during the development of each individual female that carries the chromosomal gene. This requires the expression of the mutant gene during fetal development when gonad primordia are established or during maturation of oocytes in adult life. Provided that such a selection mechanism exists, it is difficult to understand why it should not be used to protect the carrier of the gene itself from developing symptoms, rather than the next, and only the next, generation offspring. 


\section{Genomic imprinting}

In their extensive study of the genetics of HD, Myers $e t a l^{8}$ came to the conclusion that the HD gene modification is a single generation parental effect and that the hypothesis of extrachromosomal maternal factors modifying onset of HD is not sufficient to account for all observations, at least if one does not invoke selection for a protection factor in each individual generation. We therefore suggest that, rather than cytoplasmic modifiers, the interaction of chromosomal determinants whose provision is sex specific with the HD gene should be considered. The evidence for such parent specific genomic imprinting comes mainly from experimental embryology in the mouse and is briefly summarised here.

It is widely accepted now that embryogenesis to term in the mouse and probably in all mammals requires the presence of both the maternal and the paternal set of chromosomes. ${ }^{12} 13$ In experimental embryos, a diploid set of maternal chromosomes (gynogenones) or of paternal chromosomes (androgenones) cannot compensate for the lack of the parental chromosomes from the opposite sex, and hence, these embryos die in utero. The same applies to the human equivalent of the androgenetic embryo, the complete hydatidiform mole. ${ }^{14}$ Moreover, moles in the human and androgenetic embryos in the mouse show a strikingly similar phenotype. ${ }^{14} 15$ Finally, uniparental disomy of particular chromosomes can result in specific phenotypes in the mouse and has recently also been implicated in genetic disease in the human. ${ }^{16-18}$ These observations indicate that chromosomes of probably all mammals carry germline specific instructions that result in similar functions.

We have proposed that germline specific modifications of homologous chromosomes occur when they are segregated during gametogenesis. ${ }^{19}$ These modifications replicate along with parental chromosomes in embryos ${ }^{20}$ and distinguish some maternal and paternal alleles or regions until late in development. ${ }^{21} 22$ Such imprinted information can apparently result in differential activity of parental alleles. ${ }^{21}$ Imprints have to be erased during gametogenesis and new modifications have to be introduced according to the sex of the developing organism. ${ }^{19}$ That means that germline specific modifications have to be reversible within a single generation.

We and others have recently shown that there are indeed molecular differences between homologous alleles in the mouse..$^{22-25}$ The degree of methylation of DNA in particular chromosomal regions depended on whether this region was inherited from the mother or from the father. Most importantly, in six out of seven examples studied, the paternal allele was relatively undermethylated as compared $\stackrel{\mathbb{\Phi}}{\rightarrow}$ to the maternal one. In one case, undermethylation $\overrightarrow{\bar{F}}$ of the paternal gene correlated with its expression and the gene was switched off when passed through the maternal germline. ${ }^{24}$ In one study of an extensive pedigree, it was shown that modifications based on DNA methylation were reversible within single $₫$ generations. ${ }^{22}$ It should be noted that in another क pedigree, in which a different marker was segregating, $\vec{O}$ switching of the methylation pattern was incomplete. While hypermethylation was observed after each $\vec{\omega}$ maternal transmission, hypomethylation upon $\stackrel{5}{S}$ paternal transmission occurred only in about $50 \%$ of cases and in the other $50 \%$ the methylation pattern iv remained unchanged. ${ }^{23}$ An extreme example of this or phenomenon has recently been reported, in which $\vec{N}$ switching in the male germline was never observed. ${ }^{25} \%$ In addition to the particular allele under study, it is $\mathscr{c}$ possible that the likelihood of paternal switching will also depend on the genetic background of the person.

On the whole it appears that the degree of DNA methylation, and consequently expression, of certain alleles in the mammalian genome can be strongly dependent upon parental origin.

\section{Hypothesis and testing}

Both Erickson ${ }^{26}$ and Cattanach ${ }^{17}$ have suggeste that genomic imprinting could play a role in the parental origin effect observed in HD. Indeed, the apparent lack of a significant difference between mother-offspring correlation and father-offspring correlation, as well as the absence of a multigenerational maternal lineage effect, support this notion. Moreover, there seems to be no significant difference between the correlation of age at onset in half sibs who share an affected mother and those who share an affected father, whereas the cytoplasmic inheritance model predicts a stronger correlation in half sibs sharing an affected mother. ${ }^{27}$

We propose that the relatively earlier onset of symptoms in HD patients that inherit the gene from $\mathrm{O}$ their father is determined by germline specific genomic imprinting of the gene, leading to an early or high level expression of the gene product. In contrast, maternal transmission of the gene results $\Omega$ in modification, possibly by methylation of DNA, N that correlates with delayed or reduced expression, N thereby leading to a later onset of the disorder. The 0 HD gene, whether mutant or wildtype, could reside in a chromosomal region of the genome that is subject to chromosomal imprinting. Expression of $\stackrel{\mathbb{Q}}{\rightarrow}$ the wild type gene would, in this case, also be influenced by parental origin. The HD region of $\overline{0}$ human chromosome $4^{28}$ is syntenic with a region on 
chromosome 5 in the mouse ${ }^{29}$ which is, by genetic criteria, not subject to imprinting. ${ }^{16}$

While there is no evidence for or against evolutionary conservation of imprinted segments, there is an alternative to the above hypothesis. The HD mutation could result in the creation of a DNA sequence that changes 'in cis' the chromatin organisation of a domain surrounding the mutation. This signal sequence could be looked upon differently in female versus male gametogenesis and could thus determine a differentially imprinted domain dependent on parental origin. The HD gene, whether allelic or non-allelic to the mutation, would then respond to differential modification by differential expression. Again it should be stressed that switching could be incomplete, in particular with male transmission. Hence, the effect of parental origin on chromosomal modification could be influenced by genetic background and could therefore vary extensively between unrelated families. Indeed, dramatic differences in the expression of the paternal transmission effect have been described for kindreds of different ethnical provenance. ${ }^{30}$

\section{METHYLATION DIFFERENCES}

The HD gene has been localised to the telomeric region of the short arm of chromosome $4 .^{2831} \mathrm{~A}$ variety of DNA markers spanning hundreds of kilobases in this region are now available. ${ }^{28} 31-33$ These markers recognise restriction fragment length polymorphisms (RFLPs) genetically linked to HD. Thus, within informative disease families, as well as in normal families, maternal and paternal DNA sequences that map to the region of the HD gene can be analysed for their methylation status. The use of pulsed field electrophoresis in conjunction with these RFLP markers will allow a maternally and a paternally determined 'methylation profile' of this region of chromosome 4 to be derived. ${ }^{34}$ Paternally derived alleles should be relatively undermethylated if the whole region is imprinted.

It is of obvious importance to include in this analysis families in which there are drastic examples of early onset.$^{30}$ Should there be a strong correlation between undermethylation and early onset, methylation analysis could be of enormous value in predictive testing of potential carriers of the gene. ${ }^{35}$

\section{EXPRESSION DIFFERENCES}

Once the HD gene itself is cloned, and provided that the mutation creates base changes in the transcribed region, expression of the mutant allele can be compared between maternal and paternal transmission cases in necropsy material. The distinguishable wild type allele would thereby serve as an internal control. Difficulties in obtaining suitable material for the analysis of mRNA or inability to distinguish maternal from paternal transcription could necessitate the development of an animal model.

\section{TRANSGENIC MICE}

The mutant gene, once isolated and shown to be conserved among mammalian species, can be introduced into the mouse germline to produce transgenic mice. Ideally, expression of the mutant gene over the background of two copies of the wild type gene will produce a disease equivalent in the mouse. Even if these mice do not develop symptoms, or if they develop symptoms that differ from HD in the human, expression of the gene can still be analysed for parental origin effects. DNA constructs can be engineered that contain various amounts of sequences upstream or downstream of the gene, that may include signals for imprinting. Alternatively, however, if no expression differences depending on transmission from father or mother are observed, the native chromosomal domain in which the HD gene resides (chromosome 4) may confer the parental origin effect.

\section{Conclusions}

Previous observations on the effect of parental origin of the HD gene on the age at onset of the disease in offspring, together with recent experimental data on genomic imprinting, make it seem likely that the parental origin effect is determined by allelic germline specific modification of the HD gene. This proposal is also supported by a recent statistical analysis of HD families. ${ }^{36}$ Most of the aspects of the model presented here are amenable to experimental analysis. It is possible that genetic disorders other than $\mathrm{HD}$, in which the parental origin of the gene plays an important role, are also under the influence of genomic imprinting. Myotonic dystrophy is certainly the most prominent example in this category, ${ }^{37}$ but all disorders for which a cytoplasmic component of inheritance has been postulated earlier should be reconsidered ${ }^{39}$ Finally, the statement made by Hayden and Beighton ${ }^{40}$ in 1982 in their genetic analysis of HD that the "hypothetical modifiers [of age at onset] are more likely to be autosomal, although they must also be sex associated" is both ironic and prophetic, because it describes the very features of genomic imprinting.

I thank Azim Surani, Maja Bucan, and Jonathan Howard for valuable discussion. Part of this work was supported by a fellowship from EMBO. The author is a fellow of the Lister Institute of Preventive Medicine. 


\section{References}

${ }^{1}$ Merritt AD, Conneally PM, Kahman NF, Drew AL. Juvenile Huntington's chorea. In: Barbeau A, Brunett JR, eds. Progress in neuro-genetics. Amsterdam: Excerpta Medica, 1969:645-50.

2 Barbeau A. Parental ascent in the juvenile form of Huntington's chorea. Lancet 1970;ii:937.

${ }^{3}$ Boehnke M, Conneally PM, Lange K. Two models for a maternal factor in the inheritance of Huntington disease. Am J Hum Genet 1983;35:845-60.

${ }^{4}$ Myers RH, Madden JJ, Teague JL, Falek A. Factors related to onset age of Huntington disease. Am J Hum Genet 1982;34: 481-8.

5 Newcombe RG, Walker DA, Harper PS. Factors influencing age at onset and duration of survival in Huntington's chorea. Ann Hum Genet 1981;45:387-96.

6 Myers RH, Goldman D, Bird ED, et al. Maternal transmission in Huntington's disease. Lancet 1983;i:208-10.

${ }^{7}$ Hall JG, Te-Juatco L. Association between age of onset and parental inheritance in Huntington's chorea. Am J Med Genet 1983;16:289-90.

${ }^{8}$ Myers RH, Cupples LA, Schoenfeld M, et al. Maternal factors in onset of Huntington disease. Am J Hum Genet 1985;37: 511-23.

9 Farrer LA. Conneally PM. A genetic model for age at onset in Huntington disease. Am J Hum Genet 1985;37:350-7.

10 Brackenridge CJ. Familial correlations for age at onset and age at death in Huntington's disease. J Med Genet 1972;9:23-32.

1 Walker DA, Harper PS, Newcombe RG, Davies K. Huntington's chorea in South Wales: mutation, fertility, and genetic fitness. J Med Genet 1983;20:12-7.

12 McGrath J. Solter D. Completion of mouse embryogenesis requires both the maternal and paternal genomes. Cell 1984;37: 179-83.

13 Surani MAH, Barton SC. Norris ML. Development of reconstituted mouse eggs suggests imprinting of the genome during gametogenesis. Nature 1984;308:548-50.

14 Bagshawe KD, Lawler SD. Unmasking moles. Br J Obstet Gynaecol 1982;89:255-7.

15 Barton SC, Surani MAH, Norris ML. Role of paternal and maternal genornes in mouse development. Nature 1984;311: 374-6.

16 Searle AG, Beechey CV. Noncomplementation phenomena and their bearing on nondisjunctional effects. In: Dellarco VL, Voytek PE, Hollaender A, eds. Aneuploidy: etiology and mechanisms. New York: Plenum Press, 1985:363-76.

17 Cattanach BM. Parental origin effects in mice. J Embryol Exp Morphol 1986;97(suppl):137-50.

18 Spence JE, Perciaccante RG, Greig GM, et al. Uniparental disomy as a mechanism for human genetic disease. Am J Hum Genet 1988;42:217-26.

19 Surani MAH, Reik W, Norris ML, Barton SC. Influence of germline modifications of homologous chromosomes on mouse development. J Embryol Exp Morphol 1986;97(suppl):123-36.

20 Surani MAH, Barton SC, Norris ML. Nuclear transplantation in the mouse: heritable differences between parental genomes after activation of the embryonic genome. Cell 1986;45:127-36.

21 Cattanach BM, Kirk M. Differential activity of maternally and paternally derived chromosome regions in mice. Nature 1985 315:496-8.

22 Reik W, Collick A, Norris ML, Barton SC. Surani MAH. Genomic imprinting determines methylation of parental alleles in transgenic mice. Nature 1987;328:248-51.
23 Sapienza C, Peterson AC, Rossant J, Balling R. Degree of $\stackrel{\mathbb{P}}{\rightarrow}$ methylation of transgenes is dependent on gamete of origin. Nature 1987;328:251-4

24 Swain JL, Stewart TA, Leder P. Parental legacy determines methylation and expression of an autosomal transgene: a $\frac{C}{\sigma}$ molecular mechanism for parental imprinting. Cell 1987;50: 719-27.

${ }^{25}$ Hadchouel M, Farza H, Simon D, Tiollais P, Pourcel C. $\stackrel{\mathbb{D}}{\varrho}$ Maternal inhibition of hepatitis B surface antigen gene expression in transgenic mice correlates with de novo methylation. क Nature 1987;329:454-6.

${ }^{26}$ Erickson RP. Chromosomal imprinting and the parent transmission specific variation in expressivity of Huntington disease. $\mathrm{Am} \overrightarrow{\vec{\omega}}$ J Hum Genet 1985;37:827-9.

27 Brackenridge CJ. A statistical study of half-sibships born to parents affected with Huntington's disease. J Med Genet 1972;9: $17-22$.

28 Gusella JF, Wexler NS, Conneally PM, et al. A polymorphic $\mathrm{N}$ DNA marker genetically linked to Huntington's disease. Nature $\overrightarrow{\mathrm{N}}$ 1983;306:234-8.

29 Searle AG, Peters J, Lyon MF, Evans EP, Edwards JH, Buckle VJ. Chromosome maps of man and mouse, III. Genomics $\mathrm{G}$ 1987;1:3-18.

${ }^{30}$ Folstein SE, Phillips JA, Meyers DA, et al. Huntington's disease: two families with differing clinical features show linkage to the G8 probe. Science 1985;229:776-9.

31 Gilliam TC, Tanzi RE, Haines JL, et al. Localisation of the Huntington's disease gene to a small segment of chromosome $4 \frac{\mathbb{Q}}{3}$ flanked by D4S10 and the telomere. Cell 1987;50:565-71.

32 Gilliam TC, Bucan M, MacDonald ME, et al. A DNA segment encoding two genes very tightly linked to Huntington's disease. Science 1987;238:950-2.

33 Smith B, Skarecky D, Bengtsson U, Magenis RE, Carpenter Wasmuth JJ. Isolation of DNA markers in the direction of the Huntington's disease gene from the G8 locus. Am J Hum Genes 1988;42:335-44.

${ }^{34}$ Barlow DP, Lehrach $\mathrm{H}$. Genetics by gel electrophoresis: the impact of pulsed field gel electrophoresis on mammalian genetics. Trends Genet 1987;3:167-71.

35 Harper PS, Sarfarazi M. Genetic prediction and family structure in Huntington's chorea. $\mathrm{Br}$ Med $J$ 1985;290:1929-31.

${ }^{36}$ Ridley RM, Frith CD, Crow TJ, Conneally PM. Anticipation in Huntington's disease is inherited through the male line but may originate in the female. J Med Genet 1988;25:589-95.

${ }^{37}$ Harper PS. Congenital myotonic dystrophy in Britain. II. Genetic basis. Arch Dis Child 1975;50:514-21.

${ }^{38}$ Roses AD, Harper PS, Bossen EH. Myotonic muscular dystrophy. In: Vinken PJ, Bruyn GW, eds. Handbook of clinical neurology. New York: North-Holland, 1979:485-531.

39 Merril CR, Harrington MG. The search for mitochondrial inheritance of human diseases. Trends Genet 1985;1:140-4.

40 Hayden MR, Beighton P. Genetic aspects of Huntington's chorea: results of a national survey. Am J Med Genet 1982;11: $135-41$.

Correspondence and requests for reprints to Dr W Reik, Department of Molecular Embryology, $\stackrel{N}{\circ}$ Institute of Animal Physiology and Genetics $\mathbb{N}^{N}$ Research, Babraham Hall, Cambridge CB2 4AT. ㅇ 